\title{
Improving the quality of hospital care for children by supportive supervision: a cluster randomized trial, Kyrgyzstan
}

\author{
Marzia Lazzerini, ${ }^{a}$ Venera Shukurova, ${ }^{b}$ Marina Davletbaeva, ${ }^{c}$ Kubanychbek Monolbaev, ${ }^{\mathrm{d}}$ Tatiana Kulichenko, ${ }^{e}$ \\ Yuri Akoev, ${ }^{e}$ Maya Bakradze, ${ }^{e}$ Tea Margieva, ${ }^{e}$ llya Mityushino, ${ }^{e}$ Leyla Namazova-Baranova, Elnura Boronbayeva, ${ }^{f}$ \\ Aigul Kuttumuratova, ${ }^{9}$ Martin Willy Weber ${ }^{9} \&$ Giorgio Tamburlini ${ }^{a}$
}

\begin{abstract}
Objective To determine whether periodic supportive supervision after a training course improved the quality of paediatric hospital care in Kyrgyzstan, where inappropriate care was common but in-hospital postnatal mortality was low.

Methods In a cluster, randomized, parallel-group trial, 10 public hospitals were allocated to a 4-day World Health Organization (WHO) course on hospital care for children followed by periodic supportive supervision by paediatricians for 1 year, while 10 hospitals had no intervention. We assessed prospectively 10 key indicators of inappropriate paediatric case management, as indicated by WHO guidelines. The primary indicator was the combination of the three indicators: unnecessary hospitalization, increased iatrogenic risk and unnecessary painful procedures. An independent team evaluated the overall quality of care.

Findings We prospectively reviewed the medical records of 4626 hospitalized children aged 2 to 60 months. In the intervention hospitals, the mean proportion of the primary indicator decreased from $46.9 \%$ (95\% confidence interval, $\mathrm{Cl}: 24.2$ to 68.9$)$ at baseline to $6.8 \%(95 \% \mathrm{Cl}$ : 1.1 to 12.1 ) at 1 year, but was unchanged in the control group $(45.5 \%, 95 \% \mathrm{Cl}: 25.2$ to 67.9 , to $64.7 \%, 95 \% \mathrm{Cl}: 43.3$ to 86.1$)$. At 1 year, the risk ratio for the primary indicator in the intervention versus the control group was 0.09 ( $95 \% \mathrm{Cl}: 0.06$ to 0.13 ). The proportions of the other nine indicators also decreased in the intervention group ( $P<0.0001$ for all). Overall quality of care improved significantly in intervention hospitals. Conclusion Periodic supportive supervision for 1 year after a training course improved both adherence to WHO guidelines on hospital care for children and the overall quality of paediatric care.
\end{abstract}

Abstracts in عربي, 中文, Français, Русский and Español at the end of each article.

\section{Introduction}

Hospital care of an adequate quality is essential for health and well-being and is a basic component of human rights. ${ }^{1,2}$ Moreover, reducing inequalities in the quality of care is a primary objective of Health 2020, ${ }^{1}$ a strategic policy document issued by the 53 Member States in the World Health Organization's (WHO) European Region. ${ }^{1}$ Although data on the quality of hospital care for children in countries with constrained resources are starting to accumulate, ${ }^{3-16}$ very little is known about which interventions are most effective for enhancing quality. The approach most commonly advocated by WHO for improving case management for common children's diseases has been the dissemination of evidence-based guidelines, usually combined with staff training. ${ }^{4-7,17}$ Many countries implementing the Integrated Management of Childhood Illness strategy developed by WHO and the United Nations Children's Fund have adopted this approach. However, recent evidence indicates that training alone does not ensure better case management and, even after training, it may be difficult to incorporate new knowledge into practice. ${ }^{18-20}$ Supportive supervision for staff has been proposed as an intervention for increasing adherence to clinical guidelines. ${ }^{20-22}$ However, little high-quality evidence, for example from randomized controlled trials, is available on the efficacy of supportive supervision in general or, more specifically, on its use for improving the quality of hospital care for common childhood conditions in low- and middle-income countries. ${ }^{17}$

Previous assessments of the quality of paediatric care in the Commonwealth of Independent States showed that in-hospital postnatal case fatality rates were low but inappropriate case management was common and characterized by unnecessary hospitalization, overdiagnosis and overtreatment, possibly associated with wasted resources and a risk to children's health. ${ }^{3-6}$ The main underlying reasons were a lack of up-to-date, evidence-based guidelines and the persistence of outdated clinical practices. ${ }^{3-6}$

In Kyrgyzstan, a lower-middle-income country in the WHO European Region, the mortality rate in children younger than 5 years has decreased steadily from 63 per 1000 live births in 1994 to 24 per 1000 in 2013. ${ }^{23}$ In 2012, the Kyrgyz Ministry of Health and WHO agreed to implement a project aimed at improving the quality of hospital paediatric care. This project included an impact evaluation in the form of a cluster randomized controlled trial.

This paper presents the findings of this cluster randomized controlled trial, which was designed to determine whether periodic supportive supervision, provided after a standard

a World Health Organization Collaborating Centre for Maternal and Child Health, Institute for Maternal and Child Health IRCCS Burlo Garofolo, Via dell'Istria 65/1, Trieste, 34137, Italy.

b State Medical Institute of Postgraduate and Continuous Training, Bishkek, Kyrgyzstan.

'Republican Clinical Infectious Diseases Hospital, Bishkek, Kyrgyzstan.

'World Health Organization Country Office, Bishkek, Kyrgyzstan.

Scientific Centre of Children's Health, Moscow, Russian Federation.

${ }^{\mathrm{f}}$ Ministry of Health, Bishkek, Kyrgyzstan.

${ }^{9}$ Department of Child and Adolescent Health, World Health Organization Regional Office for Europe, Copenhagen, Denmark.

Correspondence to Marzia Lazzerini (email: marzia.lazzerini@burlo.trieste.it).

(Submitted: 10 May 2016 - Revised version received: 17 October 2016 - Accepted: 24 October 2016 - Published online: 20 December 2016) 
WHO 4-day training course, improves paediatric case management in hospitals and increases the overall quality of care for common childhood conditions.

\section{Methods}

We conducted a cluster, randomized, parallel-group trial in the Chui, Issyk-Kul and Talas Regions of northern Kyrgyzstan and involved 20 district and regional public hospitals that treated children (Fig. 1). Hospitals were taken as the unit of randomization to avoid contamination between practitioners at the same location. After a baseline assessment using WHO's Hospital care for children: quality assessment and improvement tool, ${ }^{24}$ which compares case management with guidelines in WHO's Pocket book of hospital care for children, ${ }^{25} 10$ hospitals were randomized to the intervention while 10 continued with usual care (Fig. 2). For randomization, hospitals were first stratified by geographical distribution (i.e. west versus east) and by type (i.e. regional versus district hospitals), then randomized by extraction of opaque sealed envelopes prepared by WHO.

\section{Fig. 1. Flow diagram, study on improving paediatric hospital care by supportive supervision of staff, Kyrgyzstan, 2012-2014}

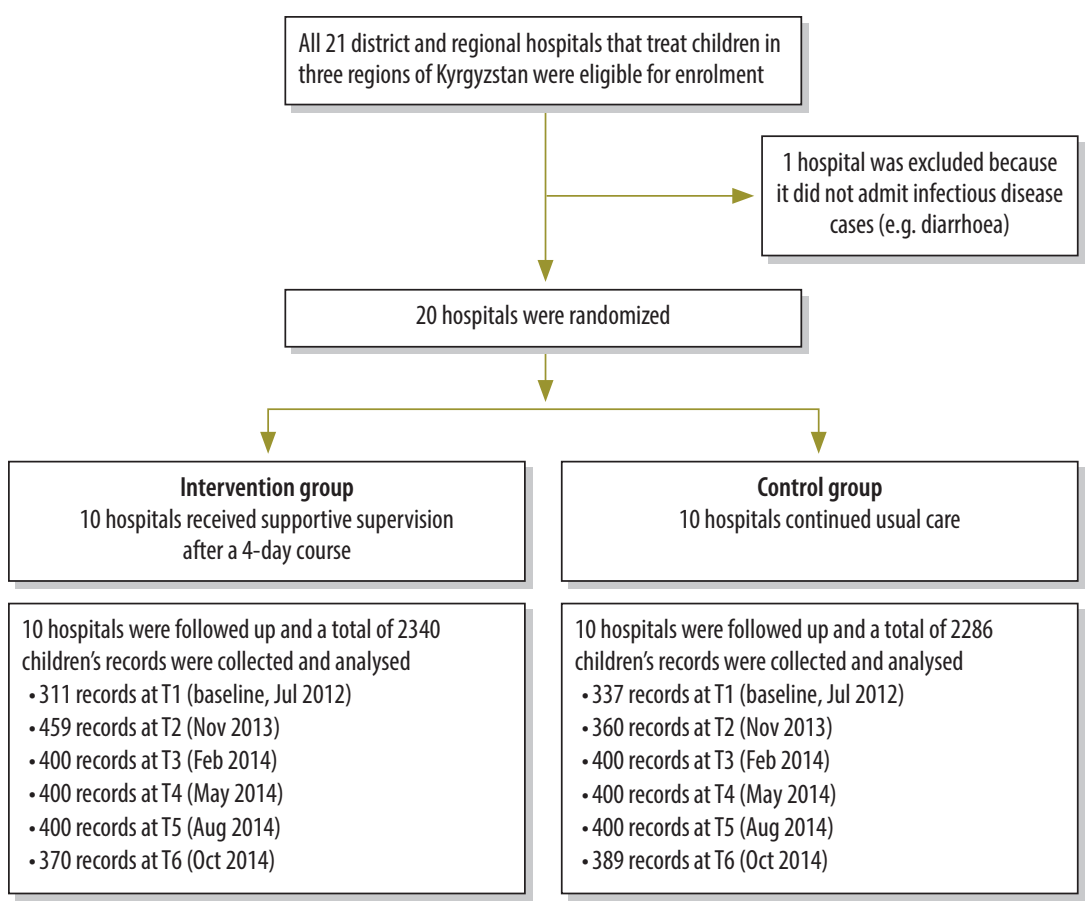

T: time point

Note: The intervention comprised periodic supportive supervision for 1 year after a standard World Health Organization 4-day training course.

\section{Fig. 2. Schedule, study on improving paediatric hospital care by supportive supervision of staff, Kyrgyzstan, 2012-2014}

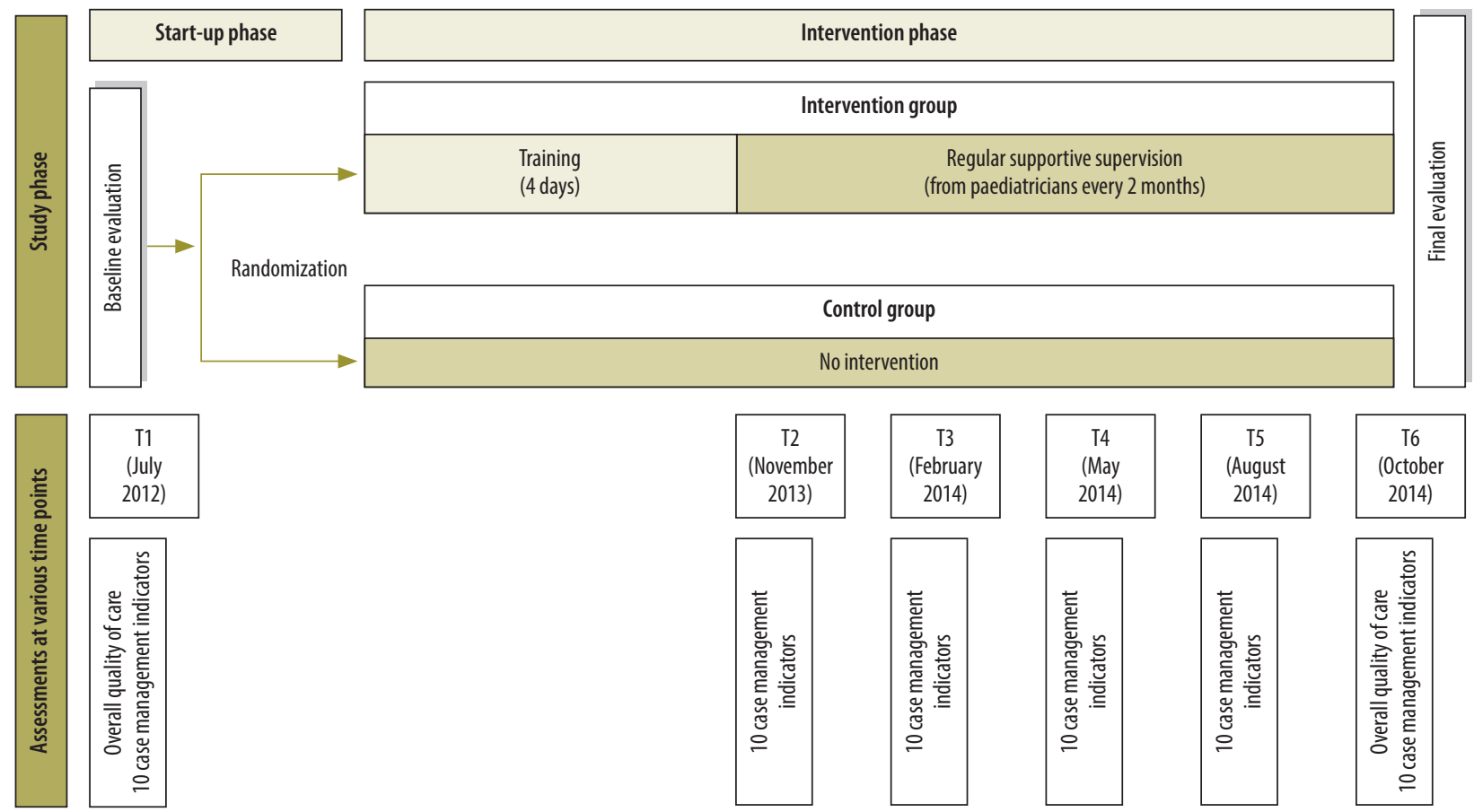

Notes: The overall quality of care was assessed using the World Health Organization's Hospital care for children: quality assessment and improvement too ${ }^{4}{ }^{4}$ and the Pocket book of hospital care for children: guidelines for the management of common illnesses with limited resources. ${ }^{25}$ The 10 case management indicators were also obtained from Hospital care for children: quality assessment and improvement tool. ${ }^{24}$ The assessment at time point T2 took place shortly after the training course and at almost the same time as the first supportive supervision visit. 
Doctors in charge of children from the intervention hospitals attended a 4-day, WHO training course on WHO's guidelines on hospital care for children. ${ }^{25}$ In collaboration with the health ministry, the WHO country office coordinated the course, which was held in the capital Bishkek, supervised by the WHO Regional Office for Europe. Subsequently, a team of eight senior national paediatricians, who had undergone training on both WHO's guidelines and supportive supervision methods, provided supervision for doctors, nurses and managers every 2 months for 1 year. The WHO country office regularly checked that supportive supervision was provided on time. During each hospital visit, two paediatricians provided supportive supervision over 1 or 2 days based on a peer-to peer, plan-do-study-act model, ${ }^{26}$ which involved: (i) identifying and agreeing on the actions needed to improve the quality of care; (ii) implementing those actions; (iii) monitoring progress; and (iv) discussing any additional actions needed. Document templates were used for these activities and training was reinforced at each subsequent visit.

\section{Outcomes}

The primary aim of the study was to determine whether or not case management was inappropriate when compared with guidelines in WHO's Pocket book of hospital care for children; ${ }^{25}$ this was evaluated using 10 key indicators in WHO's Hospital care for children: quality assessment and improvement tool (Table 1). ${ }^{24}$ Our primary indicator was the combination of the three indicators: unnecessary hospitalization, an increased risk of iatrogenic effects and unnecessary painful procedures. Our primary study outcome was the change in the mean proportion of hospitalized children, who had medical records documenting the primary indicator. For both intervention and control groups, 10 trained data collectors obtained data prospectively from paper-based medical records on the 10 indicators. Data collection time points (T) were designated T1 (July 2012), T2 (November 2013), T3 (February 2014), T4 (May 2014), T5 (August 2014) and T6 (October 2014; Fig. 2). At each time point, data collectors examined in each hospital the medical records of a random sample of 35 to 40 children aged 2 to 60 months who had been hospitalized in the previous 2 months at each hospital and who presented with: (i) a cough or breathing difficulties; (ii) diarrhoea; or (iii) fever - all common in childhood. Data collectors filled in a paper-based template for the indicators. Subsequently, two data collector coordinators transferred this information into a predefined electronic spreadsheet, which they then sent to the study investigators by email. The study investigators checked the spreadsheets for internal consistency after each data collection.

At the baseline assessment (i.e. time point T1), health staff, data collectors, patients and data analysts were all blinded to the study allocation group. During the intervention (i.e. T2 to T6), neither hospital staff nor the supportive supervision team could be blinded but they were not involved in data collection or data analysis. Data collectors knew the allocation group but were not involved in data analysis. However, children and their families were blinded to both the allocation group and the characteristics of the intervention.

In addition, an independent team of international consultant paediatricians assessed the overall quality of care delivered at each hospital at time points T1 and T6 using WHO's Hospital care for children: quality assessment and improvement tool (Fig. 2), adapted for use in the WHO European Region. ${ }^{24}$ The tool systematically assesses different components of the health system that contribute to quality of care - it includes three main sections and a total of 17 subsections. The main sections are: (i) hospital support systems; (ii) case management; and (iii) policies and organization of care. Using structured checklists in the assessment tool, the team attributed a score to each of approximately 250 items based on standards derived from WHO recommendations and other relevant guidelines. ${ }^{24,25}$ During the evaluations, a summary score was derived for each of the 17 subsections: it ranged from 0 for totally inadequate care to 3 for care that met international standards.

To ensure data quality, we (i) fieldtested the template used for collecting data on indicators of inappropriate case management, which included an explicit definition of each indicator, before being used in the study; (ii) field-tested data collectors' performance before the study and their understanding was reinforced, if necessary, to ensure consistency; (iii) rotated data collectors among hospitals to reduce the influence of subjectivity; (iv) determined the reliability of the data collectors in evaluating medical records by comparing their evaluations with those of a team of independent international paediatricians at time points T1, T2 and T6 (Fig. 2); and (v) monitored the completeness and internal consistency of the data collected by an external independent data analyst at regular intervals after each supportive supervision visit.

The ethical committees of the Kyrgyz State Medical Institute of Postgraduate and Continuous Training and of the Institute for Maternal and Child Health IRCCS Burlo Garofolo in Italy approved the study. In addition, the director of each participating hospital gave informed consent. The privacy of children and their families was protected by collecting data anonymously. Data are reported in accordance with the Consolidated Standards of Reporting Trials (CONSORT) statement for cluster randomized controlled trial $^{27}$ and the trial is registered with ClinicalTrials.gov under the identifier NCT02001116.

\section{Statistical analysis}

Using data from the baseline assessment study, we calculated the sample size required by taking into account: (i) the fixed number of clusters; (ii) the intracluster correlation coefficient determined at the baseline assessment; (iii) the expected effect of the intervention; and (iv) the desired power of the study. ${ }^{28,29}$ In the baseline assessment, the proportion of the primary indicator was $45 \%$ and the intracluster correlation coefficient was 0.16 . Under the hypothesis that the proportion of children who satisfied the conditions for the primary indicator would decrease after the intervention by 35 percentage points in the intervention group and by 10 percentage points in the control group, we estimated that a total of 640 children (i.e. 32 at each of the 20 facilities) had to be evaluated at each time point to detect a significant difference between the two groups with a power of $80 \%$ and a significance of $90 \%(\alpha=5 \%$, two-sided test).

We present categorical variables as absolute numbers, proportions and risk ratios (RRs) with $95 \%$ confidence intervals (CIs) and quantitative vari- 
ables as means and standard deviations. We used Fisher's exact test or Yates's corrected $\chi^{2}$ test, as appropriate, to compare categorical variables and $t$ test and the mean difference to compare quantitative variables. Trends in proportions were compared using the Cochran-Armitage $\chi^{2}$ test. All statistical tests were two-sided and a $P$-value less than 0.05 was considered statistically significant. We analysed data using Stata version 12 (StataCorp. LP, College Station, United States of America) and OpenEpi version 2.3.1 (Andrew G Dean and Kevin M Sullivan, Atlanta, USA).

\section{Table 1. Indicators of inappropriate paediatric case management, WHO Quality assessment and improvement tool for hospital care for children $^{24}$}

\begin{tabular}{|c|c|c|}
\hline Indicator & Definition & Examples \\
\hline $\begin{array}{l}\text { Combined negative } \\
\text { indicator (primary } \\
\text { indicator) }\end{array}$ & $\begin{array}{l}\text { Concomitant presence in the same child of: } \\
\text { (i) unnecessary hospitalization; (ii) increased } \\
\text { iatrogenic risk; and (iii) unnecessary painful } \\
\text { procedures }\end{array}$ & See descriptions of individual components \\
\hline $\begin{array}{l}\text { Unnecessary } \\
\text { hospitalization }\end{array}$ & $\begin{array}{l}\text { Failure to comply with recommendations on } \\
\text { hospitalization in WHO's Pocket book of hospital care } \\
\text { for children }^{25}\end{array}$ & $\begin{array}{l}\text { (i) The child had "no pneumonia: cough or cold" according } \\
\text { to WHO pocket book criteria and did not satisfy the criteria } \\
\text { for "severe pneumonia" (thereby requiring hospitalization) } \\
\text { but was hospitalized; (ii) the child had "some dehydration" } \\
\text { according to WHO criteria and did not satisfy the criteria for } \\
\text { "severe dehydration" but was hospitalized }\end{array}$ \\
\hline Incorrect diagnosis & $\begin{array}{l}\text { Failure to comply with WHO pocket book } \\
\text { recommendations on diagnosis }\end{array}$ & $\begin{array}{l}\text { (i) The child had "no pneumonia: cough or cold" according } \\
\text { to WHO pocket book criteria but was diagnosed with } \\
\text { "pneumonia" or "severe pneumonia"; (ii) the child had "some } \\
\text { dehydration" according to WHO criteria but was diagnosed } \\
\text { with "severe dehydration" }\end{array}$ \\
\hline Incorrect treatment & $\begin{array}{l}\text { Failure to comply with WHO pocket book } \\
\text { recommendations on treatment }\end{array}$ & $\begin{array}{l}\text { (i) The child should have received treatment for "no } \\
\text { pneumonia: cough or cold" according to WHO pocket } \\
\text { book criteria but was treated for "pneumonia" or "severe } \\
\text { pneumonia"; (ii) the child had "some dehydration" according } \\
\text { to WHO criteria but was treated for "severe dehydration" }\end{array}$ \\
\hline $\begin{array}{l}\text { Inconsistent diagnosis } \\
\text { and treatment }\end{array}$ & $\begin{array}{l}\text { There was no consistency between diagnosis and } \\
\text { treatment or the diagnosis was not described clearly } \\
\text { in the patient's chart }\end{array}$ & $\begin{array}{l}\text { (i) The child was diagnosed with "pneumonia" according } \\
\text { to WHO pocket book criteria but was treated for "severe } \\
\text { pneumonia"; (ii) the child had "some dehydration" according } \\
\text { to WHO criteria but was treated for "severe dehydration" }\end{array}$ \\
\hline Increased iatrogenic risk & $\begin{array}{l}\text { Administration of two or more unnecessary drugs } \\
\text { as indicated by a failure to comply with WHO pocket } \\
\text { book recommendations on case management }\end{array}$ & $\begin{array}{l}\text { The administration of any unnecessary drug (i.e. a drug not } \\
\text { recommended by the WHO pocket book) whose efficacy } \\
\text { was not proven and which had possible adverse effects, e.g. } \\
\text { steroids or antibiotics for diarrhoea, sedatives for children with } \\
\text { fever and so-called cardiotonic or neuroprotective drugs in } \\
\text { children without a clear indication for such treatment }\end{array}$ \\
\hline $\begin{array}{l}\text { Unnecessary painful } \\
\text { procedures }\end{array}$ & $\begin{array}{l}\text { Performance of unnecessary invasive procedures as } \\
\text { indicated by a failure to comply with WHO pocket } \\
\text { book recommendations on case management }\end{array}$ & $\begin{array}{l}\text { (i) Intramuscular or intravenous antibiotic injections in a } \\
\text { child who, according to WHO pocket book criteria, should } \\
\text { have been treated with an oral antibiotic (e.g. a child } \\
\text { with "pneumonia" and no vomiting or signs of "severe } \\
\text { pneumonia"); (ii) administration of intravenous fluids to a child } \\
\text { who, according to WHO criteria, could have been rehydrated } \\
\text { orally (e.g. a child with diarrhoea but with "no dehydration" } \\
\text { or "some dehydration" according to WHO criteria and without } \\
\text { repetitive vomiting }\end{array}$ \\
\hline Inadequate monitoring & $\begin{array}{l}\text { Inadequate monitoring for the clinical diagnosis } \\
\text { received, as indicated by WHO pocket book criteria }\end{array}$ & $\begin{array}{l}\text { (i) Failure to monitor the respiratory rate at least twice a day } \\
\text { in a child with a respiratory infection; (ii) failure to monitor } \\
\text { weight at least twice a day in a child with diarrhoea; (iii) failure } \\
\text { to monitor neurological status at least twice a day in a child } \\
\text { with meningitis }\end{array}$ \\
\hline $\begin{array}{l}\text { Nutritional status not } \\
\text { assessed }\end{array}$ & Failure to assess growth or identify malnutrition & $\begin{array}{l}\text { (i) Failure to assess a child's growth adequately, as indicated by } \\
\text { WHO pocket book criteria (i.e. measurement of both weight- } \\
\text { for-age and height-for-age and comparison with WHO } 2006 \\
\text { growth standards); (ii) failure to identify a child with acute or } \\
\text { chronic malnutrition according to WHO criteria }\end{array}$ \\
\hline $\begin{array}{l}\text { Incorrect use of } \\
\text { intravenous fluids }\end{array}$ & $\begin{array}{l}\text { Fluids not used in accordance with WHO pocket } \\
\text { book recommendations }\end{array}$ & $\begin{array}{l}\text { (i) Intravenous fluids were prescribed when they were } \\
\text { not needed (e.g. when the child was able to drink); (ii) the } \\
\text { wrong type of fluid was given (e.g. a hypotonic solution); } \\
\text { (iii) the wrong quantity was given (i.e. too much or too little); } \\
\text { (iv) fluids were given at the wrong interval }\end{array}$ \\
\hline
\end{tabular}




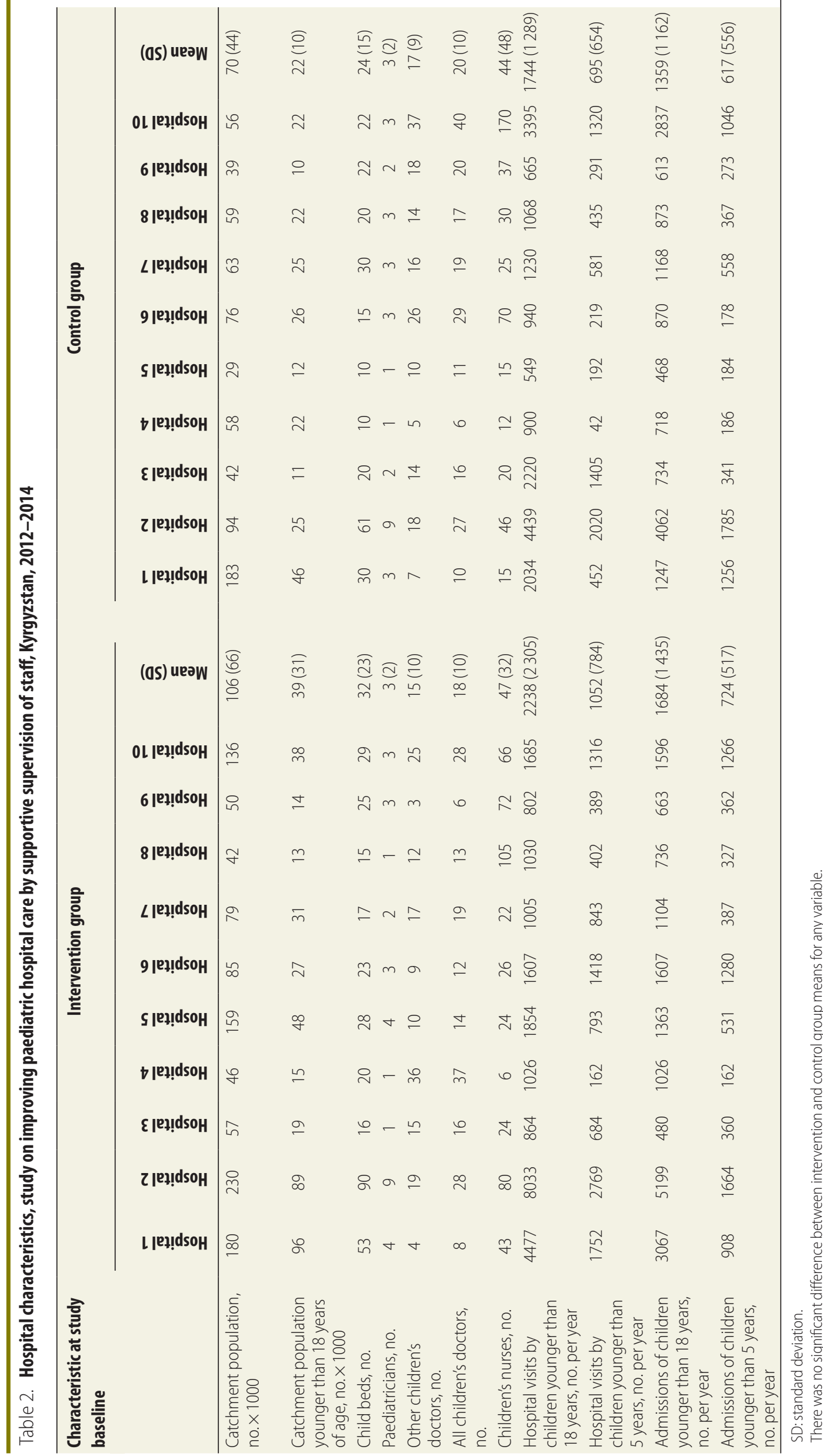




\section{Results}

Table 2 gives details of the hospitals involved in the study. There was no significant difference in any characteristic between intervention and control groups. In total, data on 4626 children were collected and analysed over the six time points: 2340 in the intervention group and 2286 in the control group. At baseline, there was no significant difference between the groups for any of the 10 indicators of inappropriate case management.

During the study period, similar trends were observed for all indicators (Fig. 3). In particular, the primary indicator decreased significantly from $46.9 \%$

\section{Fig. 3. Proportion of children with one of the $\mathbf{1 0}$ indicators of inappropriate paediatric case management, study on improving paediatric hospital care by supportive supervision of staff, Kyrgyzstan, 2012-2014}
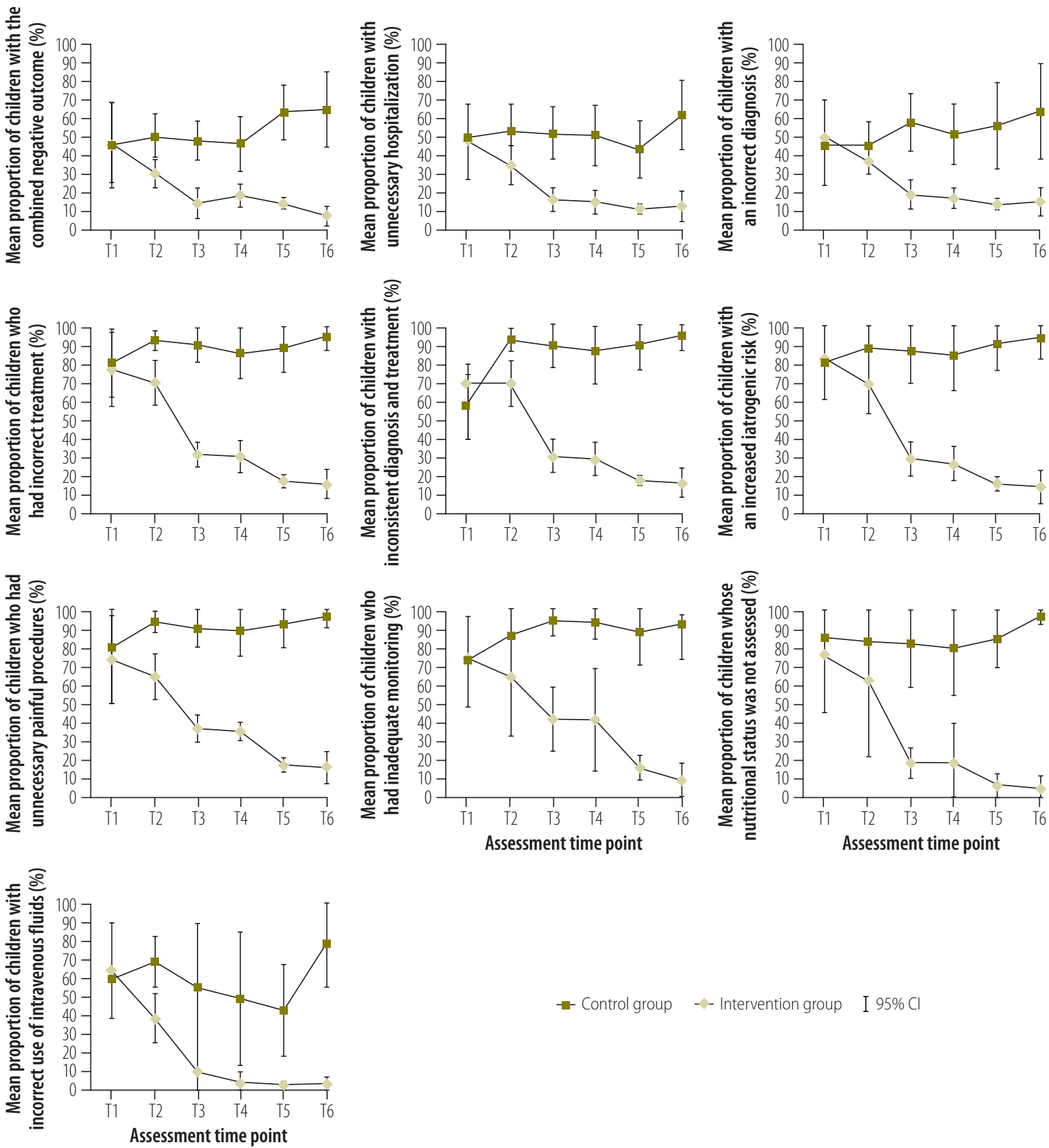

Notes: Groups were randomized and each group consisted of 10 hospitals. The timing of assessments at time points T1 to T6 is described in Fig. 2 . The intervention comprised periodic supportive supervision for 1 year after a standard World Health Organization 4-day training course. Details of the number of children's medical records examined at each time point are given in Fig. 1. The combined negative indicator was the combination of the three indicators of: (i) unnecessary hospitalization; (ii) increased iatrogenic risk; and (iii) unnecessary painful procedures. The indicators were obtained from the World Health Organization's Hospital care for children: quality assessment and improvement tool. ${ }^{24}$ and are described in Table 1. 
(95\% CI: 24.2 to 68.9 ) at $\mathrm{T} 1$ to $6.8 \%$ (95\% CI: 1.1 to 12.1$)$ at T6 ( $P$ for trend $<0.0001)$ in the intervention hospitals. No significant change was observed in control hospitals, $45.5 \%$ (95\% CI: 25.2 to 67.9 ) at $\mathrm{T} 1$ to $64.7 \%$ (95\% CI: 43.3 to 86.1 ) at T6 (P for trend $>0.05)$. At T6, the RR for the primary indicator in the intervention versus the control group was 0.09 (95\% CI: 0.06 to 0.13 ). The mean proportion of unnecessary hospitalization also decreased over time in the intervention group from $47.6 \%$ (95\% CI: 27.5 to 67.7 ) at T1 to $13.1 \%$ (95\% CI: 5.0 to 21.2 ) at T6 ( $P$ for trend $<0.001)$, but remained stable in the control group (RR in the intervention versus the control group at T6: $0.23 ; 95 \%$ CI: 0.17 to 0.30 ). Similarly, the mean proportion of an incorrect diagnosis decreased significantly in the intervention group from $49.7 \%$ (95\% CI: 29.9 to $69.5)$ at $\mathrm{T} 1$ to $14.7 \%$ (95\% CI: 7.0 to 22.4$)$ at T6 ( $P$ for trend $<0.0001$ ), but not in the control group (RR in the intervention group at T6: 0.22 ; $95 \%$ CI: 0.17 to $0.29)$. The mean proportion of incorrect treatment decreased significantly only in the intervention group, from $77.9 \%$ (95\% CI: 57.6 to 98.2 ) at $\mathrm{T} 1$ to $15.7 \%$ (95\% CI: 7.4 to 24.0 ) at T6 ( $P$ for trend $<0.0001)$; the RR in the intervention group at T6 was 0.16 (95\% CI: 0.12 to 0.29 ). A similar pattern was observed for the other six indicators and the RR in the intervention versus the control group was: 0.16 (95\% CI: 0.13 to 0.21 ) for an inconsistency between diagnosis and treatment; 0.14 (95\% CI: 0.11 to 0.19 ) for increased iatrogenic risk; 0.15 (95\% CI: 0.12 to 0.20 ) for unnecessary painful procedures; 0.09 (95\% CI: 0.07 to 0.13 ) for inadequate monitoring; 0.05 (95\% CI: 0.03 to 0.08 ) for failure to assess nutritional status; and 0.03 (95\% CI: 0.02 to 0.06 ) for inadequate use of fluids.

At baseline, there was no significant difference between intervention and control hospitals in quality-of-care summary scores for the 17 subsections of WHO's Hospital care for children: quality assessment and improvement tool. ${ }^{24}$ In contrast, summary scores at the end of the intervention period were significantly higher in the intervention than the control group (Table 3). Additional details of the changes observed and of residual problems that are amenable to future quality improvements are available from the corresponding author.

\section{Discussion}

We found that a standard, 4-day, WHO training course followed by periodic supportive supervision from national, trained paediatricians every 2 months for 1 year significantly reduced inappropriate case management of hospitalized children and improved the overall quality of paediatric care. Our findings add to the existing literature ${ }^{30-32}$ and indicate that supportive supervision can improve both adherence to clinical guidelines and the overall quality of care.

Our study was a pragmatic trial because it was conceived as part of an implementation project rather than being performed in a so-called pure study setting. Nevertheless, the supportive supervision team comprised highly motivated and trained staff and external monitoring was carried out regularly to ensure that supportive supervision was

\section{Table 3. Quality of children's care, by study group, study on improving paediatric hospital care by supportive supervision of staff, Kyrgyzstan, 2012-2014}

\begin{tabular}{|c|c|c|c|c|c|c|}
\hline \multirow[t]{3}{*}{ Quality-of-care categorya } & \multicolumn{6}{|c|}{ Summary score } \\
\hline & \multicolumn{3}{|c|}{ Baseline } & \multicolumn{3}{|c|}{ End of the study } \\
\hline & $\begin{array}{l}\text { Intervention } \\
\text { group, mean } \\
\text { (SD) }\end{array}$ & $\begin{array}{l}\text { Control } \\
\text { group, } \\
\text { mean (SD) }\end{array}$ & $\begin{array}{l}\text { Intervention versus } \\
\text { control group, mean } \\
\text { difference }(95 \% \mathrm{Cl})\end{array}$ & $\begin{array}{l}\text { Intervention } \\
\text { group, mean } \\
\text { (SD) }\end{array}$ & $\begin{array}{l}\text { Control } \\
\text { group, mean } \\
\text { (SD) }\end{array}$ & $\begin{array}{l}\text { Intervention versus } \\
\text { control group, mean } \\
\text { difference }(95 \% \mathrm{CI})\end{array}$ \\
\hline \multicolumn{7}{|l|}{ Hospital support systems } \\
\hline Information systems and statistics & $1.85(0.44)$ & $1.70(0.53)$ & $0.15(-0.30$ to 0.60$)$ & $2.68(0.24)$ & $1.55(0.52)$ & $1.26(0.85$ to 1.66$)$ \\
\hline Drugs and equipment & $2.27(0.61)$ & $2.00(0.73)$ & $0.27(-0.36$ to 0.90$)$ & $2.94(0.11)$ & $1.68(0.60)$ & 1.13 (0.74 to 1.51$)$ \\
\hline Laboratory & $2.50(0.46)$ & $2.33(0.57)$ & $0.17(-0.31$ to 0.66$)$ & $2.93(0.12)$ & $2.28(0.80)$ & 0.65 (0.11 to 1.18$)$ \\
\hline Emergency support & $1.69(0.28)$ & $1.51(0.33)$ & $0.18(-0.10$ to 0.46$)$ & $2.85(0.13)$ & $1.27(0.50)$ & 1.58 (0.23 to 1.92$)$ \\
\hline Paediatric ward & $1.65(0.40)$ & $1.54(0.55)$ & $0.11(-0.34$ to 0.56$)$ & $2.85(0.19)$ & $1.60(0.50)$ & 1.25 (0.89 to 1.60$)$ \\
\hline \multicolumn{7}{|l|}{ Case management } \\
\hline Cough and breathing difficulties & $1.02(0.63)$ & $0.99(0.51)$ & $0.01(-0.52$ to -0.54$)$ & $2.53(0.33)$ & $1.17(0.62)$ & 1.36 (0.89 to 1.82$)$ \\
\hline Diarrhoea & $0.65(0.58)$ & $0.60(0.54)$ & $0.05(-0.47$ to 0.57$)$ & $2.70(0.21)$ & $1.12(0.48)$ & 1.58 (0.23 to 1.92$)$ \\
\hline Anaemia & $1.12(0.37)$ & $1.09(0.43)$ & $0.03(-0.25$ to 0.31$)$ & $2.28(0.31)$ & $0.98(0.70)$ & 1.30 (0.79 to 1.80$)$ \\
\hline Febrile conditions & $0.87(0.43)$ & $0.96(0.39)$ & $-0.09(-0.47$ to 0.29$)$ & $2.12(0.31)$ & $1.16(0.37)$ & 0.96 (0.63 to 1.28$)$ \\
\hline Chronic conditions & $1.72(0.67)$ & $2.17(0.29)$ & $-0.45(-0.93$ to 0.03$)$ & $1.73(0.35)$ & $0.97(0.31)$ & 1.76 (0.44 to 1.07$)$ \\
\hline Surgery & $1.46(0.39)$ & $1.29(0.26)$ & 0.17 (-0.14 to 0.48$)$ & $2.88(0.17)$ & $1.40(0.59)$ & 1.48 (1.07 to 1.88$)$ \\
\hline \multicolumn{7}{|l|}{ Policies and organization of care } \\
\hline Supportive care & $1.00(0.56)$ & $1.08(0.48)$ & $-0.08(-0.57$ to 0.41$)$ & $2.87(0.13)$ & $1.25(0.55)$ & $1.62(0.24$ to 1.99$)$ \\
\hline Child-friendly services & $1.25(0.32)$ & $1.43(0.36)$ & $-0.18(-0.50$ to 0.14$)$ & $2.69(0.26)$ & $1.20(0.44)$ & 1.49 (1.15 to 1.82$)$ \\
\hline Monitoring & $0.96(0.78)$ & $1.20(0.57)$ & $-0.24(-0.88$ to 0.40$)$ & $2.76(0.21)$ & $0.91(0.57)$ & 1.85 (1.84 to 2.25$)$ \\
\hline Auditing and guidelines & $1.74(0.51)$ & $1.69(0.31)$ & 0.05 (-0.34 to 0.44$)$ & $2.73(0.19)$ & $1.56(0.74)$ & 1.17 (0.66 to 1.67$)$ \\
\hline Access to hospital & $2.00(0.28)$ & $2.03(0.43)$ & $-0.03(-0.37$ to 0.31$)$ & $2.76(0.26)$ & $1.85(0.37)$ & 0.91 (0.60 to 1.21$)$ \\
\hline Mothers'satisfaction & $1.72(0.62)$ & $1.70(0.32)$ & $0.02(-0.44$ to 0.48$)$ & $2.83(0.19)$ & $1.89(0.23)$ & 0.94 (0.74 to 1.13$)$ \\
\hline
\end{tabular}

$\mathrm{Cl}$ : confidence interval; SD: standard deviation.

a Quality-of-care categories relate to sections and subsections of the World Health Organization's Hospital care for children: quality assessment and improvement tool. ${ }^{24}$ 
provided on time. The results of the study cannot be directly generalized to situations in which a lack of equipment, drugs, supplies or human resources is a major problem or to places where a different form of supportive supervision is being used (e.g. lower-intensity supportive supervision, less-well-trained staff or no external monitoring).

In line with other studies on quality improvement interventions, our outcomes were process outcomes (i.e. indicators of case management quality compared with reference guidelines) rather than health outcomes. ${ }^{30,31}$ We did not assess mortality or morbidity because in-hospital, postneonatal mortality in countries in the WHO European Region is too low to be used for evaluating interventions and because, to be reliable, data on morbidity (such as the proportion of children with complications from common diseases) should be collected at hospital, primary care and community levels. For this study, we selected the measures of inappropriate case management on the basis of previous experience with evaluating the quality of hospital care in countries in the Commonwealth of Independent States, which showed that unnecessary hospitalization, incorrect diagnosis, incorrect treatment, a lack of monitoring and a lack of attention to comprehensive care (e.g. to nutrition) were the main problems. ${ }^{3-6}$ These assessment methods are the most reliable and universally accepted, standardized, quantitative indicators currently available for evaluating the quality of paediatric hospital care in settings where mortality is low. Should better indicators become available in the future, they should be considered for use in further research.

A limitation of the study is that the data collectors were not blinded to the allocation group. However, information about the 10 indicators of inappropriate case management was collected from medical records, which are legal documents and, as such, should be considered reliable, and the assessment was based on predefined case definitions, criteria and reference standards, ${ }^{25}$ In addition, the reliability of the data collectors' evaluations of medical records was examined at time points T1, T2 and T6 and found to be very high: Cohen's kappa coefficient for inter-rater agreement between data collectors and a team of international independent paediatricians was 0.82 , 0.89 and 0.91 at the three time points, respectively. Moreover, it is unlikely that the large differences in quality of care observed between intervention and control hospitals can be explained by the influence of subjectivity.

We did not include cost, patient satisfaction or the satisfaction of health-care providers as study outcomes. However, the administrative data collected suggested that the cost of drugs, especially parenteral drugs, in most intervention hospitals had decreased and interviews with staff and patients indicated anecdotally that satisfaction had increased. Future studies should include a cost-effectiveness analysis and evaluate staff and patient satisfaction. In addition, future research should investigate which approach to supportive supervision results in the greatest improvements in different settings. The existing literature suggests that supportive supervision must be tailored to the local context to some extent. For example, low- or moderate-intensity supportive supervision can be effective in some settings, whereas high-intensity supervision may be needed in others to bring about real changes in behaviour, knowledge and practices. ${ }^{19-21,30-33}$ In our study, improvements in all indicators of inappropriate case management were already apparent by time point T3 (i.e. within 6 months of the first supportive supervision visit), which suggested that the intensity of supportive supervision could be decreased in the following period should improvements be observed.
The ideal providers of supportive supervision may vary according to the setting. In our study and a study in Kenya, ${ }^{30}$ the supportive supervision team comprised paediatricians; of two trials performed in primary care, the providers were paediatricians in one $\mathrm{e}^{31}$ and medical officers and staff supervising the Integrated Management of Childhood Illness in the other. ${ }^{32}$ The characteristics of the ideal provider may depend on who is receiving supportive supervision: adequately trained medical officers may be able to provide effective supportive supervision to primary care staff, whereas a team of experienced paediatricians may be needed for hospital staff.

The intervention hospitals in our study should be further assessed after a longer period of time to determine whether the improvements observed are maintained. Future studies in these hospitals and in different contexts elsewhere should identify the most cost-effective way of providing effective supportive supervision over the long term. Furthermore, projects should also aim to improve case management in primary care and to strengthen referral systems, thereby ensuring better coordination between different levels of care. Our results indicate that policy-makers should consider using supportive supervision to increase adherence to evidence-based guidelines for paediatric hospital care.

\section{Acknowledgements}

We thank supportive supervision team members Jyldyz Artykbaeva, Janara Botbaeva, Dinara Kabajeva, Marath Kalyev, Tursun Mamyrbaeva, Zaure Ospanova and Baktigul Shalabaeva.

Funding: The study was financed by the Russian Federation within a project entitled Improving the quality of paediatric care in pilot hospitals in the Kyrgyz Republic.

Competing interests: None declared.

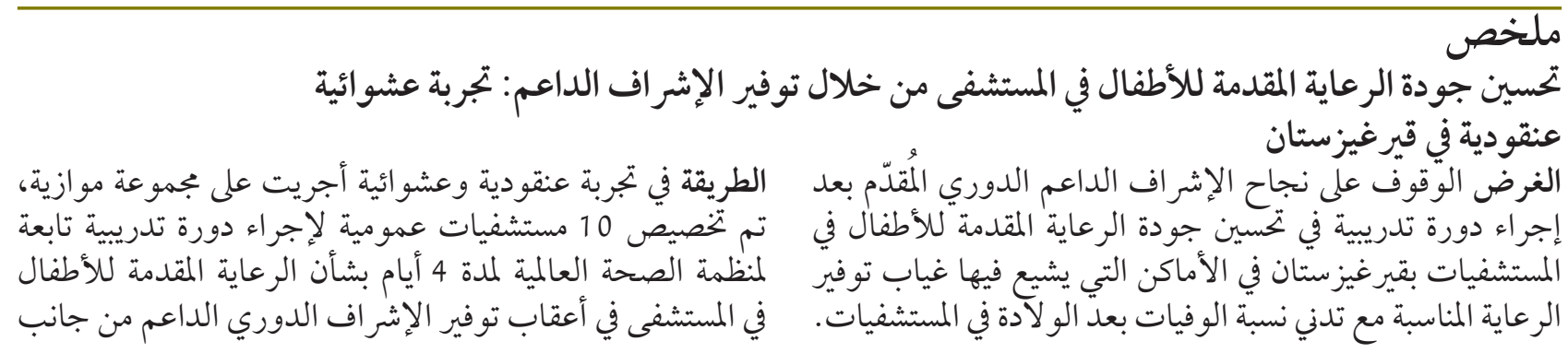




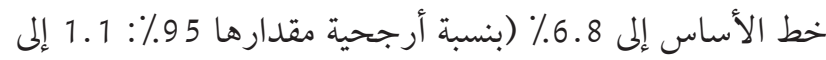

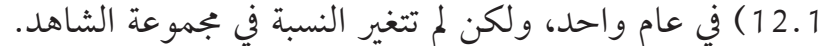

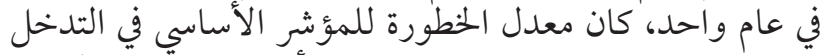

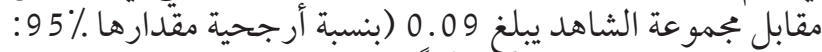

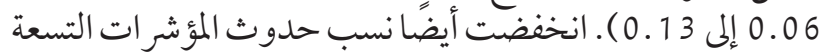

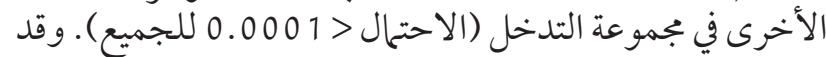

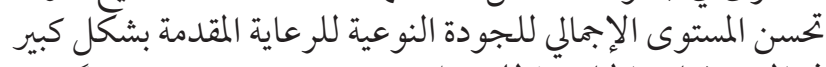

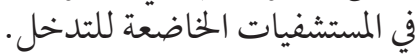

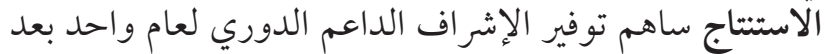

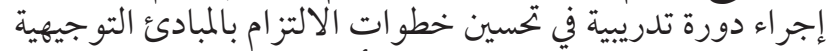

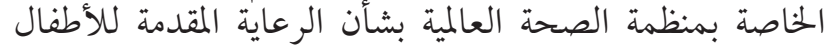

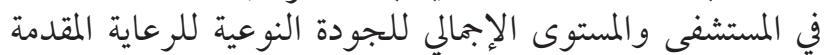

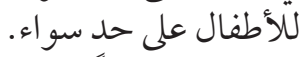

أطباء الأطفال لمدة عام واحد، بينما لم تخضع أي من المستشفيات

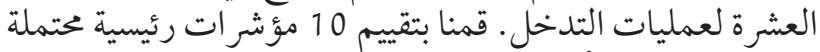

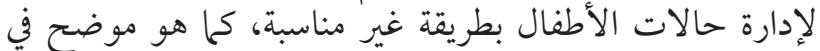

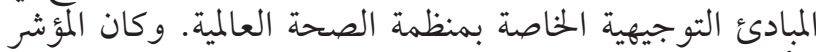

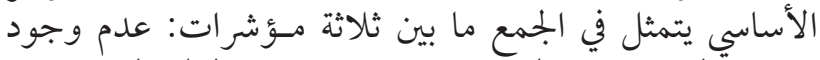

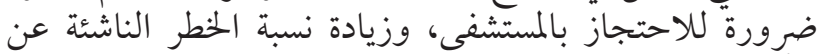

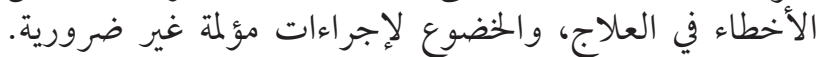
وقام فريق مستقل بتقييم المستوى الإجمالي للجودة المجات النوعية للرعاية

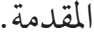

النتائج قمنا بإجراء مراجعة استباقية للسجلات الطبية للأطفالٍ

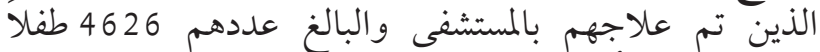

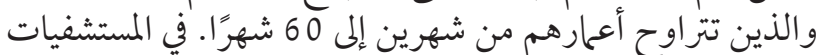

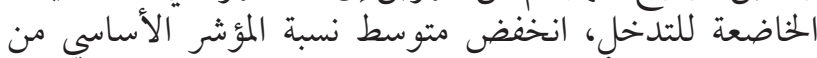

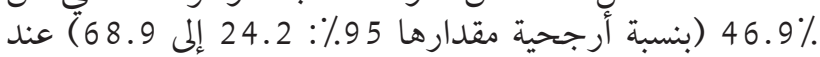

\section{摘要 \\ 目的旨在确定培训课程结束后开展定期支持性监督是 否能够改善吉尔吉斯斯坦儿童医院护理的质量。在吉 尔吉斯斯坦, 护理不当很常见, 但住院产后死亡率较 低。 \\ 方法 在一项整群随机平行组试验中, 安排 10 家公 立医院开展为期 4 天的世界卫生组织 (WHO) 儿童医 院护理课程, 随后由儿科医生进行为期 1 年的定期支 持性监督,在此期间, 不对 10 家医院进行任何干预。 按照 WHO 指南的说明, 我们对不当儿科病历管理的 10 项关键指标进行了预期性评估。主要指标为以下 三项指标的组合：不必要的住院治疗、医源性风险增 加以及不必要的痛苦疗程。一个独立团队对整体护理}

通过支持性监督改善儿童医院护理质量 : 整群随机试验，吉尔吉斯斯坦

\section{质量进行了评估。}

结果 我们预先审查了 4626 名 2 个月至 60 个月大 住院儿童的医疗记录。在干预医院, 1 年间主要指标 的平均比例从基准线下 46.9\% (95\% 置信区间,CI: 24.268.9) 下降至 6.8\% (95\% CI: 1.1-12.1), 但对照组无变化。 1 年后, 干预组与对照组主要指标的风险比为 $0.09(95 \%$ CI: 0.06-0.13)。千预组中的其它九项指标比例也有所 下降 (全部 $\mathrm{P}<0.0001)$ 。千预医院的整体护理质量得 到了显著改善。

结论课程结束后进行为期 1 年的定期支持性监督 既增强了对世界卫生组织 (WHO) 儿童医院护理方面 指南的遵守程度, 同时也改善了儿科护理的整体质量。

\section{Résumé}

\section{Améliorer la qualité des soins hospitaliers pédiatriques grâce à un encadrement adapté: essai randomisé par grappes au Kirghizistan}

Objectif Déterminer si un encadrement périodique adapté suite à un cours de formation a permis d'améliorer la qualité des soins hospitaliers pédiatriques au Kirghizistan, où il était courant que les soins soient inappropriés, mais où la mortalité postnatale en milieu hospitalier était faible

Méthodes Dans le cadre d'un essai en groupes parallèles randomisé par grappes, 10 hôpitaux publics ont bénéficié d'une formation de 4 jours sur les soins hospitaliers pédiatriques dispensée par l'Organisation mondiale de la Santé (OMS), suivie d'un encadrement périodique adapté par des pédiatres pendant 1 an, alors que 10 autres hôpitaux n'ont reçu aucune intervention. Nous avons préalablement évalué 10 indicateurs clés de prise en charge inappropriée de cas pédiatriques, conformément aux directives de I'OMS. L'indicateur principal était la combinaison des trois indicateurs: hospitalisation inutile, risque iatrogène accru et procédures douloureuses inutiles. Une équipe indépendante a évalué la qualité générale des soins.

Résultats Nous avons préalablement examiné les dossiers médicaux de 4626 enfants hospitalisés âgés de 2 à 60 mois. Dans les hôpitaux ayant bénéficié d'une intervention, la proportion moyenne de l'indicateur principal a chuté de $46,9 \%$ (intervalle de confiance, IC, à 95\%: de 24,2 à 68,9) à 6,8\% (IC à 95\%: de 1,1 à 12,1) au bout d'une année, mais est restée inchangée dans le groupe de contrôle. Au bout d'un an, le risque relatif pour l'indicateur principal dans le groupe expérimental par rapport au groupe de contrôle était de 0,09 (IC à 95\%: de 0,06 à 0,13). Les proportions des neuf autres indicateurs ont également diminué dans le groupe expérimental ( $P<0,0001$ pour tous). La qualité générale des soins s'est considérablement améliorée dans les hôpitaux ayant bénéficié d'une intervention.

Conclusion La mise en place d'un encadrement périodique adapté pendant 1 an à la suite d'un cours de formation permet d'améliorer à la fois la conformité aux directives de l'OMS sur les soins hospitaliers pédiatriques et la qualité générale des soins pédiatriques. 


\section{Резюме}

\section{Повышение качества стационарной медицинской помощи детям путем дополнительного надзора: кластерное рандомизированное исследование, Кыргызстан}

Цель Определить, способствует ли периодический дополнительный надзор после проведения обучающего курса повышению качества оказания стационарной педиатрической помощи в Кыргызстане, где среднестатистический уровень качества оказания медицинской помощи был невысоким, но уровень внутристационарной постнатальной смертности был низким.

Методы В ходе кластерного рандомизированного исследования с использованием параллельных групп было определено 10 государственных больниц для проведения 4-дневного обучающего курса Всемирной организации здравоохранения (ВО3) по оказанию стационарной медицинской помощи детям с проведением последующего периодического дополнительного надзора педиатрами в течение 1 года, в то время как в 10 других больницах не было проведено никакого вмешательства. Мы провели перспективную оценку 10 ключевых показателей ненадлежащего качества ведения педиатрических пациентов в соответствии суказаниями руководящихпринципов BO3. Основным показателем являлось сочетание трех факторов: госпитализации без необходимости, повышенного ятрогенного риска и проведения ненужных болезненных процедур.
Общее качество оказания медицинской помощи оценивалось независимой группой.

РезультатыМывперспективномпорядкепроверилимедицинские отчеты о 4626 госпитализированных детях в возрасте от 2 до 60 месяцев. В больницах с вмешательством средняя доля основного показателя за 1 год снизилась с 46,9\% (95\%-й доверительный интервал, ДИ: от 24,2 до 68,9) на исходномуровне до 6,8\% (95\%-й ДИ: от 1,1 до 12,1), но осталась неизменной в контрольной группе. В течение 1 года относительный риск для основного показателя в группе с вмешательством по сравнению с контрольной группой составил 0,09 (95\%-й ДИ: от 0,06 до 0,13). Доли остальных девяти показателей также снизились в группе с вмешательством ( $P<0,0001$ для всех). В целом качество медицинской помощи значительно улучшилось в больницах с вмешательством.

Вывод Периодический дополнительный надзор в течение 1 года после обучающего курса помог улучшить как соблюдение требований руководящих принципов ВО3 по стационарному медицинскому уходу за детьми, так и общее качество оказания медицинской помощи детям.

\section{Resumen}

\section{Mejora de la calidad de la asistencia hospitalaria infantil mediante supervisión de apoyo: un ensayo aleatorizado por conglomerados, Kirguistán}

Objetivo Determinar si la supervisión de apoyo periódica tras un curso de formación mejoró la calidad de la asistencia hospitalaria pediátrica en Kirguistán, donde era común una asistencia poco apropiada pero la mortalidad postnatal hospitalaria era baja.

Métodos En un ensayo aleatorizado por conglomerados paralelos, se asignó a 10 hospitales públicos un curso de 4 días de la Organización Mundial de la Salud (OMS) sobre asistencia hospitalaria infantil, seguido de una supervisión de apoyo periódica realizada por pediatras durante 1 año, mientras que 10 hospitales no tuvieron ninguna intervención. Prospectivamente, se evaluaron 10 indicadores clave de tratamiento inapropiado de los casos pediátricos, tal como indicaban las directrices de la OMS. El indicador primario fue la combinación de los tres indicadores: hospitalización innecesaria, aumento del riesgo iatrogénico y procedimientos dolorosos innecesarios. Un equipo independiente evaluó la calidad general de la asistencia.
Resultados Se revisaron prospectivamente los historiales médicos de 4626 niños hospitalizados de entre 2 y 60 meses. En los hospitales donde se intervino, el porcentaje medio del indicador primario descendió de un 46,9\% (intervalo de confianza, IC, del 95\%: 24,2 a 68,9) al inicio a un 6,8\% (IC del 95\%: 1,1 a 12,1) al cabo de un año, pero no cambió en el grupo de control. Al cabo de un año, el coeficiente de riesgo del indicador primario en el grupo de intervención, en comparación con el grupo de control, fue del 0,09 (IC del 95\%:0,06 a 0,13). Los porcentajes de los otros nueve indicadores también se redujeron en el grupo de intervención $(P<0,0001$ para todos). La calidad general de la asistencia mejoró de forma significativa en los hospitales donde se intervino.

Conclusión La supervisión de apoyo periódica durante un año tras un curso de formación mejoró tanto la adherencia a las directrices de la OMS sobre asistencia hospitalaria infantil como la calidad general de la asistencia pediátrica.

\section{References}

1. Health 2020: the European policy for health and well-being. Copenhagen: World Health Organization Regional Office for Europe; 2012. Available from: http://www.euro.who.int/en/health-topics/health-policy/health-2020-theeuropean-policy-for-health-and-well-being [cited 2015 May 12]

2. European strategy for child and adolescent health and development: from resolution to action, 2005-2008. Copenhagen: World Health Organization Regional Office for Europe; 2008. Available from: http://www.euro.who. int/en/health-topics/noncommunicable-diseases/obesity/publications/ pre-2009/european-strategy-for-child-and-adolescent-health-anddevelopment-from-resolution-to-action,-20052008 [cited 2016 Nov 22].

3. Duke T, Keshishiyan E, Kuttumuratova A, Ostergren M, Ryumina I, Stasii E, et al. Quality of hospital care for children in Kazakhstan, Republic of Moldova, and Russia: systematic observational assessment. Lancet. $2006 \mathrm{Mar}$ 18;367(9514):919-25. doi: http://dx.doi.org/10.1016/S0140-6736(06)68382 7 PMID: 16546540

4. Assessment of paediatric hospital care in Tajikistan, 2-18 July 2012 Copenhagen: World Health Organization Regional Office for Europe 2012. Available from: http://www.euro.who.int/_data/assets/ pdf_file/0005/181796/e96753-Eng.pdf [cited 2015 May 12].

5. Improving hospital care for children. Case study report. Armenia, Kazakhstan, Turkmenistan and Uzbekistan. Copenhagen: World Health Organization Regional Office for Europe; 2010. Available from: http://www. euro.who.int/__data/assets/pdf_file/0014/129002/e94562.pdf [cited 2015 May 12]

6. Intercountry meeting on improving paediatric hospital care: lessons learned, Yerevan, Republic of Armenia, 19-21 October 2010. Copenhagen: World Health Organization Regional Office for Europe; 2010. Available from: http://www.euro.who.int/ data/assets/pdf file/0008/145979/ IMCI_ARM_Oct_2010_sum.pdf?ua=1 [cited 2015 June 25]. 
7. Campbell H, Duke T, Weber M, English M, Carai S, Tamburlini G; Pediatric Hospital Improvement Group. Global initiatives for improving hospital care for children: state of the art and future prospects. Pediatrics. 2008 Apr;121(4):e984-92. doi: http://dx.doi.org/10.1542/peds.2007-1395 PMID: 18381526

8. Duke T, Tamburlini G, Silimperi D; Paediatric Quality Care Group. Improving the quality of paediatric care in peripheral hospitals in developing countries. Arch Dis Child. 2003 Jul;88(7):563-5. doi: http://dx.doi.org/10.1136/ adc.88.7.563 PMID: 12818896

9. Legido-Quigley H, McKee M, Nolte E, Glinos IA. Assuring the quality of health care in the European Union. A case for action. Observatory studies series No. 12. Geneva: World Health Organization; 2008. Available from: http://www.euro.who.int/_data/assets/pdf_file/0007/98233/E91397.pdf [cited 2016 Nov 21].

10. Tamburlini G, Schindler MR, Di Mario S, Vilarim JN, Bernardino L, et al. Assessing quality of paediatric care in developing countries. Asian J Paed Practice. 2007;11:1-11.

11. Nolan T, Angos P, Cunha AJ, Muhe L, Qazi S, Simoes EA, et al. Quality of hospital care for seriously ill children in less-developed countries. Lancet. 2001 Jan 13;357(9250):106-10. doi: http://dx.doi.org/10.1016/S01406736(00)03542-X PMID: 11197397

12. English M, Esamai F, Wasunna A, Were F, Ogutu B, Wamae A, et al. Assessment of inpatient paediatric care in first referral level hospitals in 13 districts in Kenya. Lancet. 2004 Jun 12;363(9425):1948-53. doi: http:// dx.doi.org/10.1016/S0140-6736(04)16408-8 PMID: 15194254

13. Hoque DM, Rahman M, Billah SM, Savic M, Karim AQ, Chowdhury EK, et al. An assessment of the quality of care for children in eighteen randomly selected district and sub-district hospitals in Bangladesh. BMC Pediatr. 2012 Dec 26;12(1):197. doi: http://dx.doi.org/10.1186/1471-2431-12-197 PMID: 23268650

14. Sidik NA, Lazuardi L, Agung FH, Pritasari K, Roespandi H, Setiawan T, et al.: Indonesian Paediatric Hospital Assessment Group. Assessment of the quality of hospital care for children in Indonesia. Trop Med Int Health. 2013 Apr;18(4):407-15. doi: http://dx.doi.org/10.1111/tmi.12061 PMID: 23336605

15. Baseline survey on quality of paediatric care in Tanzania. Dar es Salaam: Ministry of Health and Social Welfare, United Republic of Tanzania; 2011. Available from: http://www.who.int/childmedicines/countries/ QUALITY_TANZANIA.pdf [cited 2014 Dec 16].

16. Assessment of quality of care for children in selected hospitals in Ghana. Geneva: World Health Organization; 2011. Available from: http://apps.who. int/medicinedocs/documents/s19075en/s19075en.pdf [cited 2014 Dec 16]

17. Dettrick Z, Firth S, Jimenez Soto E. Do strategies to improve quality of maternal and child health care in lower and middle income countries lead to improved outcomes? A review of the evidence. PLoS One 2013;8(12):e83070. doi: http://dx.doi.org/10.1371/journal.pone.0083070 PMID: 24349435

18. Horwood C, Vermaak K, Rollins N, Haskins L, Nkosi P, Qazi S. An evaluation of the quality of $\mathrm{IMCl}$ assessments among $\mathrm{IMCl}$ trained health workers in South Africa. PLoS One. 2009 Jun 17;4(6):e5937. doi: http://dx.doi. org/10.1371/journal.pone.0005937 PMID: 19536288

19. Survey report to identify barriers impeding the implementation of the strategy on integrated management of childhood illness in the Republic of Tajikistan. Copenhagen: World Health Organization Regional Office for Europe; 2010. Available from: http://www.euro.who.int/en/countries/ tajikistan/publications3/survey-report-to-identify-barriers-impeding the-implementation-of-the-strategy-on-integrated-management-ofchildhood-illness-in-the-republic-of-tajikistan [cited 2016 Nov 22].

20. Pariyo GW, Gouws E, Bryce J, Burnham G; Uganda IMCI Impact Study Team. Improving facility-based care for sick children in Uganda: training is not enough. Health Policy Plan. 2005 Dec;20(90001) Suppl 1:i58-68. doi: http:// dx.doi.org/10.1093/heapol/czi051 PMID: 16306071
21. Rohde J. Supportive supervision to improve integrated primary health care. MSH Occasional Paper No. 2. Cambridge: Management Science for Health; 2006. Available from: http://www.popline.org/node/193349 [cited 2016 Nov 22]

22. Primary health care supervision manual. A guide to primary health care facility supervision. Pretoria: Quality Assurance Directorate, National Department of Health; 2009. Available from: http://www.inpracticeafrica. com/ /media/Guidelines/SA_NDOH_Primary_Supervision.pdf [cited 2016 Nov 22].

23. Kyrgyzstan. Statistics. New York: United Nations Children's Fund; 2013 Available from: http://www.unicef.org/infobycountry/kyrgyzstan_statistics. html [cited 2016 May 1].

24. Hospital care for children: quality assessment and improvement tool. Copenhagen: World Health Organisation Regional Office for Europe; 2015. Available from: http://www.euro.who.int/en/health-topics/Life-stages/ child-and-adolescent-health/publications/2015/hospital-care-for-childrenquality-assessment-and-improvement-tool [cited 2016 May 1].

25. Pocket book of hospital care for children: guidelines for the management of common illnesses with limited resources, second edition. Geneva: World Health Organization; 2013. Available from: http://apps.who.int/iris/ bitstream/10665/81170/1/9789241548373_eng.pdf [cited 2016 May 2].

26. Taylor MJ, McNicholas C, Nicolay C, Darzi A, Bell D, Reed JE. Systematic review of the application of the plan-do-study-act method to improve quality in healthcare. BMJ Qual Saf. 2014 Apr;23(4):290-8. doi: http://dx.doi. org/10.1136/bmjas-2013-001862 PMID: 24025320

27. Campbell MK, Piaggio G, Elbourne DR, Altman DG; CONSORT Group Consort 2010 statement: extension to cluster randomised trials. BMJ. 2012 Sep 04;345 sep04 1:e5661. doi: http://dx.doi.org/10.1136/bmj.e5661 PMID: 22951546

28. Hayes RJ, Bennett S. Simple sample size calculation for cluster-randomized trials. Int J Epidemiol. 1999r Apr;28(2):319-26. doi: http://dx.doi. org/10.1093/ije/28.2.319 PMID: 10342698

29. Hemming K, Girling AJ, Sitch AJ, Marsh J, Lilford RJ. Sample size calculations for cluster randomised controlled trials with a fixed number of clusters. BMC Med Res Methodol. 2011 Jun 30;11(1):102. doi: http://dx.doi. org/10.1186/1471-2288-11-102 PMID: 21718530

30. Ayieko P, Ntoburi S, Wagai J, Opondo C, Opiyo N, Migiro S, et al. A multifaceted intervention to implement guidelines and improve admission paediatric care in Kenyan district hospitals: a cluster randomised trial. PLoS Med. 2011 Apr;8(4):e1001018. doi: http://dx.doi.org/10.1371/journal. pmed.1001018 PMID: 21483712

31. Rowe AK, Onikpo F, Lama M, Osterholt DM, Rowe SY, Deming MS. A multifaceted intervention to improve health worker adherence to integrated management of childhood illness guidelines in Benin. Am J Public Health. 2009 May;99(5):837-46. doi: http://dx.doi.org/10.2105/ AJPH.2008.134411 PMID: 19299681

32. Hoque DM, Arifeen SE, Rahman M, Chowdhury EK, Haque TM, Begum K, et al. Improving and sustaining quality of child health care through IMCI training and supervision: experience from rural Bangladesh. Health Policy Plan. 2014 Sep;29(6):753-62. doi: http://dx.doi.org/10.1093/heapol/czt059 PMID: 24038076

33. Dorsey S, Pullmann MD, Deblinger E, Berliner L, Kerns SE, Thompson K, et al. Improving practice in community-based settings: a randomized trial of supervision - study protocol. Implement Sci. 2013 Aug 10;8(1):89. doi: http://dx.doi.org/10.1186/1748-5908-8-89 PMID: 23937766 